\title{
Move If U Wanna: Obama and the weight loss nudge
}

' $\mathrm{L}$ et's Move!" That's the name of the White House campaign to defeat childhood obesity. One has to admire the simplicity of this message. It reminds me of a popular rap song: "Move If U Wanna," by the band Mims. I jog to the song daily. Here's the chorus: "Move if you wanna if you wanna if you wanna" (repeat seven times). The thumping beat never fails to push me harder. The pitch rises in altitude: "I' $m$ the president, governor and May-or!!! I control everything, like a dic-tator!!”

It's interesting to compare "Move if U Wanna" to the White House's "Let's Move!" rhetoric. "Let's Move!" aims to raise "a healthier generation of kids by solving the epidemic of childhood obesity within a generation."' The White House Task Force on Childhood Obesity had input from 12 federal agencies and more than 2500 ideas from parents, teachers and health providers. On May 11, 2010 it released its 124-page report, which features 338 references and 70 recommendations including encouraging young children to follow the American Academy of Pediatrics guidelines on limiting screen time and digital media use, and disseminating "simple, actionable messages about the 2010 Dietary Guidelines for Americans through local communities."

In contrast, the ditty "Move if $\mathrm{U}$ Wanna" is not evidence-based. It was designed to sell CDs, not to make teenagers sweat calories. No obesity experts advised on the lyrics. It is not preachy - you only work out if " $U$ Wanna." It landed, inadvertently, on the Best of the Best in Workout Music: The 2009 Hip Hop Edition.

Another song on the workout hit list is "Bassment Party" [sic] by The Cool Kids. The lyrics extol acting sophomoric in bars and showing off fancy footwear (Air Jordan 5s).

America has been down the evidencebased path to fight childhood obesity for decades — and the approach has failed. Americans - and citizens elsewhere keep getting fatter despite fruits-and-veg- gies social marketing campaigns like those in the task force recommendations. We've known for at least 50 years that soda and chips are bad for us. Yet, despite public health campaigns, the share of Americans aged 40 to 74 who were eating five or more fruits and vegetables daily dropped from 42 per cent in 1988 to 26 per cent in 2006 . $^{2}$

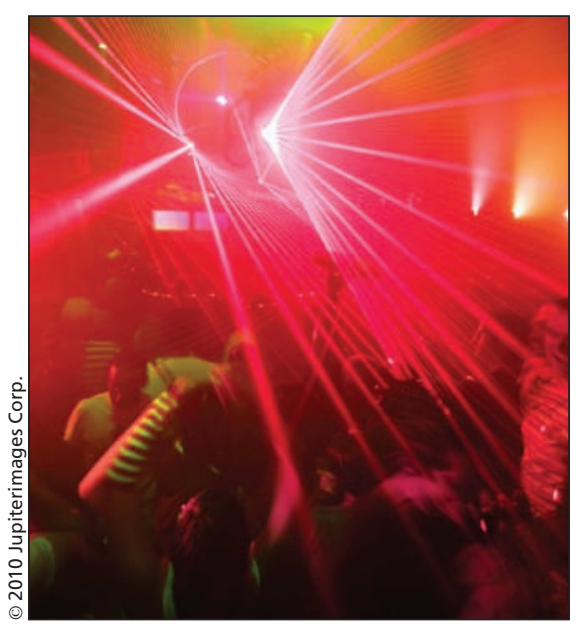

In contrast to ineffective megaphone campaigns that exhort healthy eating, successful exercise messages, like "Bassment Party" and "Move if U Wanna," have two common elements. First, their success is random, not evidence-based. What works for one person to manage her weight - like tastes in music does not work for another. Second, young people only move if the nudge melds with something they already enjoy doing, like listening to rap music.

If the First Lady wants to make a real difference, she should heed the advice of one of her husband's most trusted advisors, Cass Sunstein, who argues that to change behaviour the nudge needs to be individualized and attached to meaningful incentives. ${ }^{3}$

What kind of incentives work to change children's eating and exercise behaviour? Here's the truth: we don't know yet. As Martin Lindstrom has noted in the advertising context, people do not make purchasing decisions rationally when emotion guides decisions. ${ }^{4}$
To change behaviour we need to reward individuals financially for sustained and earnest attempts to manage their weight loss with their primary care provider over the long-term. We also need to reward primary care providers financially for crafting a lasting, individualized weight management plan.

"Veggies taste so good when they come fresh from the garden, don't they?" Mrs. Obama asked children on Sesame Street's 40th anniversary program. "If you eat all these healthy foods, you are going to grow up to be big and strong," Mrs. Obama smiled, flexing her arms. "Just like me."5 I wish tackling obesity were this simple. I applaud Mrs. Obama for encouraging parents to be better role models for their children. Yet she is mistaken if she thinks that the epidemic of childhood obesity in America is solvable using the bully pulpit of the White House. I'd put my money on "Move If U Wanna" or "Bassment Party."

\section{Neil Seeman JD MPH \\ Director \\ Health Strategy Innovation Cell \\ Massey College \\ University of Toronto \\ Toronto, Ont.}

Neil Seeman's next book is XXL: Obesity and the Limits of Shame.

\section{References}

1. Solving the problem of childhood obesity within a generation: White House Task Force on Childhood Obesity report to the President. Washington (DC): Executive Office of the President of the United States; 2010. Available: www.letsmove.gov/obesitytaskforce.php (accessed 2010 Nov. 22)

2. King DE, Mainous AG, Carnemolla M. Adherence to healthy lifestyle habits in US adults, 1988-2006. Am J Med 2009;122:528-34.

3. Thaler RH, Sunstein CR. Nudge: Improving decisions about health, wealth, and happiness. New Haven (CT): Yale University Press; 2008.

4. Lindstrom M. Buyology: Truth and lies about why we buy. New York (NY): Doubleday; 2008.

5. Stanley A. Same street, different world: 'Sesame' turns 40. New York Times. 2009 Nov. 3: AR1.

CMAJ 2011.DOI:10.1503/cmaj.101387

Do you have an opinion about this article? Post your views at www.cmaj.ca. Potential Salon contributors are welcome to send a query to salon@cmaj.ca. 